\title{
Ongoing changes at the long-term monitoring sites of Gurgler Kamm Biosphere Reserve, Tyrol, Austria
}

\author{
Roland Mayer \& Brigitta Erschbamer
}

Keywords: altitudinal gradient, diversity, frequency, functional groups, grazing, permanent plots

\section{Abstract}

By means of a long-term monitoring project, species diversity and abundance were analysed at 16 sites along an altitudinal gradient from $1960 \mathrm{~m}$ to $2830 \mathrm{~m}$ in Gurgler Kamm Biosphere Reserve (LTER site of the platform Tyrolean Alps; Obergurgl, Ötztal). A total of 108 permanent plots of $1 \mathrm{~m}^{2}$ were established. The main aim was to observe effects of time in untreated sites and impacts of grazing exclusion on species number and frequency of functional groups in different subalpine and alpine plant communities.

Grazing exclusion led to decreases in species numbers. Significant positive grazing effects were detected for dwarf shrubs and legumes in the subalpine zone and for herbs in the upper alpine zone.

Within the untreated sites, species numbers and frequencies changed significantly with time, involving almost all functional groups. The lichen heath was the most stable community. Here, only graminoids showed an increasing trend.

All in all, the intermediate disturbance hypothesis was found to be valid also for high altitudes. A continuation of the traditional grazing regime is therefore suggested for the entire Gurgler Kamm Biosphere Reserve.
Profile

Protected area

Gurgler Kamm Biosphere Reserve

Mountain range

Alps

Country

Austria

\section{Introduction}

Effects of the ongoing climate change, outlined for instance by IPCC (2007), can only be predicted by means of baseline data from consecutive long-term monitoring programmes. Recently, range shifts of species and migrations were reported by several revisitation studies from high altitudes in the Alps (Walther et al. 2005; Pauli et al. 2007, 2012; Erschbamer et al. 2006, 2009, 2011; Holzinger et al. 2008; Gottfried et al. 2012). Long-term observations are also necessary to record changes due to grazing cessation (Bohner et al. 2012). It is well known that grazing cessation causes major alterations in vegetation structure, species composition and richness in the lowlands and in the montane zone (Altesor et al. 2005; Pavlu et al. 2007; Isselstein et al. 2007; Bohner et al. 2012). An increasing number of research projects also analysed grazing effects at higher altitudes (Schneiter 1997; Camenisch \& Schütz 2000; Scheurer 2000; Kala et al. 2002; Binkley et al. 2003; Dullinger et al. 2003; Buttolph \& Coppock 2004; Jewell et al. 2007; Miller et al. 2010; Deléglise et al. 2011). However, the amplitude of grazing effects still remained unclear for high altitude plant communities.

In 2000 a long-term research programme was started in Obergurgl at Gurgler Kamm Biosphere Reserve (BR), inner Ötztal, Tyrol, Austria (Figure 1), from the subalpine to the subnival zone, to monitor floristic and faunistic changes and to measure microclimate and soil conditions at selected sites (Kaufmann 2005; Mayer et al. 2009). The BR was seen as a unique area for

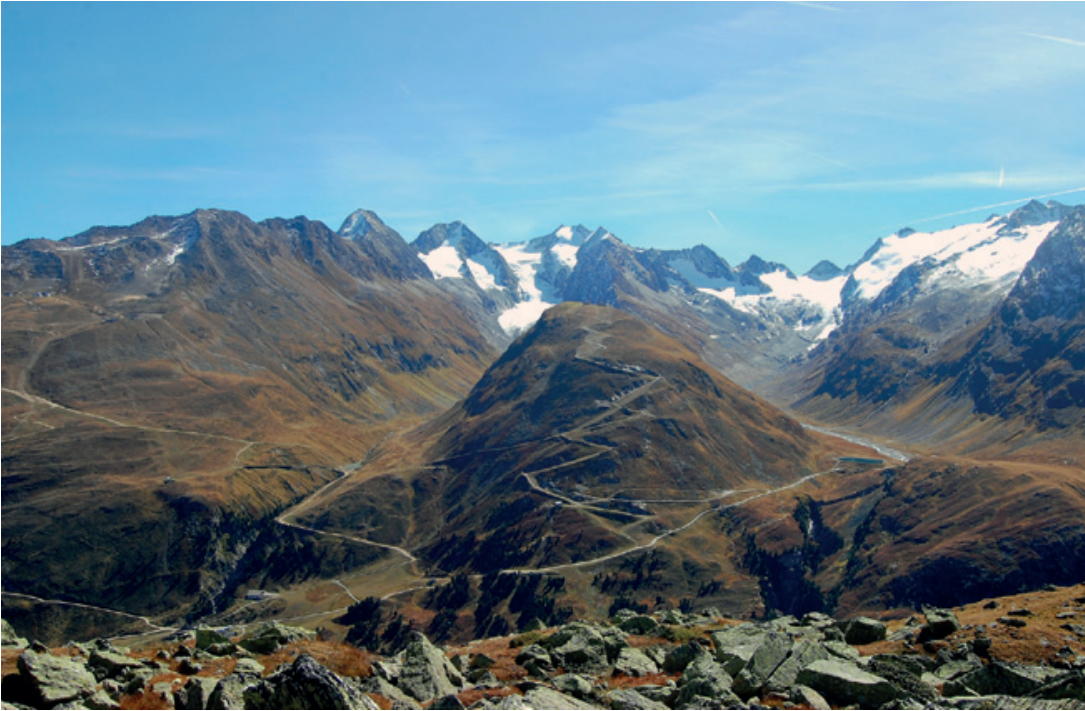

Figure 1 - Gurgler Kamm Biosphere Reserve. From left to right: Festkogel, Gaisberg valley, Hohe Mut, and Rotmoos valley. (C) Roland Mayer

developing a Long-Term Ecological Research (LTER) programme, similar to other arctic-alpine LTER sites (e.g. Niwot Ridge Colorado, Bowman \& Seastedt 2001). First steps planned for the LTER Obergurgl programme included establishing permanent plots at the most important plant communities across all altitudinal zones and monitoring species composition and frequency at regular intervals.

With its long grazing tradition going back more than 6000 years (Vorren et al. 1993) and involving thousands of sheep (Bortenschlager 2000), Gurgler Kamm BR seemed to be an ideal study area to inves- 


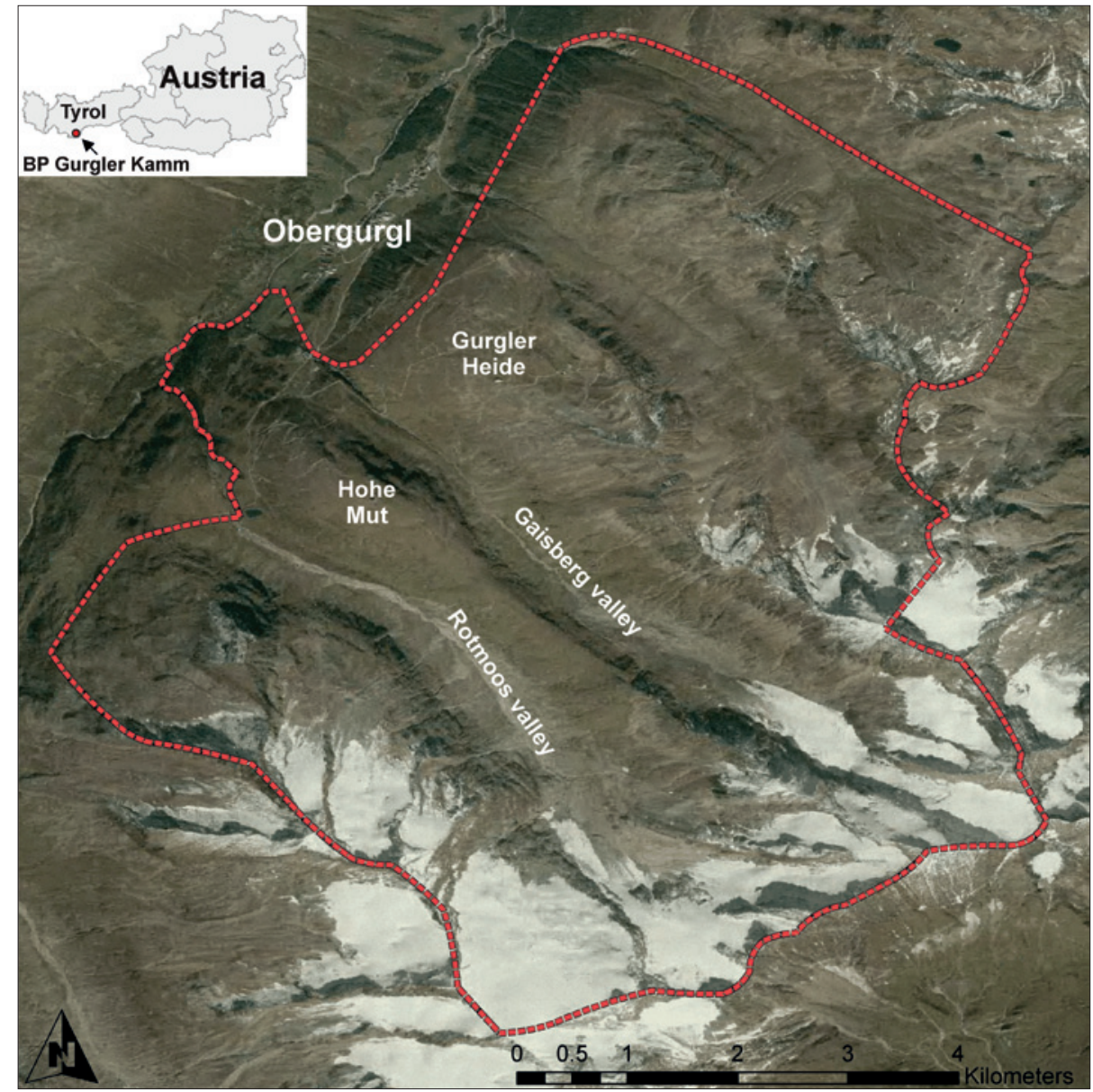

Figure 2 - Position and boundary (dotted red line) of Gurgler Kamm BR in the inner Ötrtal (Tyrol, Austria); (C) Geoimage Austria 2013

tigate effects of grazing cessation. Several grazing exclusions were established in order to contribute to the open discussion on grazing effects at high altitudes.

In this paper we will present only the results of the botanical survey. The main aim was to study plant dynamics and frequency changes throughout the years within a time frame of more than 10 years. Due to continuous warming, mainly in summer, from 1972 onwards (Kuhn et al. 2013), we expected major changes in species diversity mainly in the subalpine and lower alpine dwarf shrub heaths and grasslands by upward migrations of low-altitude species. Within the grazing exclusions, a decrease of species diversity and a prevalence of competitive species was hypothesized.

The main questions of this paper were: (1) does species number change with time (untreated sites) and grazing cessation (exclusion vs. control sites) along the altitudinal gradient? (2) does frequency of functional groups change with time (untreated sites) and grazing cessation (exclusion vs. control sites)?

\section{Material and methods}

\section{Study site}

Gurgler Kamm BR (inner Ötztal, Tyrol, Austria) covers an area of ca. 1500 ha (Figure 2). It belongs to the old generation of UNESCO biosphere reserves, established in 1977 as a result of the MAB 6 Obergurgl programme (Moser 1987; Patzelt 1987). The BR was designated by a top-down decision, more or less disregarding stakeholder processes and local circumstances.

Since 1981 , about $90 \%$ of the BR area has been under federal state protection (Rubegebiet Ötrtaler Alpen, http://www.tiroler-schutzgebiete.at/). The Ruhegebiet was also proposed as Site of Community Importance (pSCI) under the Habitats Directive and as a Special Protected Area (SPA) under the Birds Directive, and it was included in the Community List for the European Union's Natura 2000 network (Erschbamer \& Kaufmann 2006). As the BR had never really been recognized by the local authorities and residents, a redefinition according to the Seville Strategy (UNESCO 1995) was not realized till the present and therefore a retraction of the UNESCO label is conceivable.

With an extension from $1930 \mathrm{~m}$ up to more than $3400 \mathrm{~m}$, the BR includes plant communities from the subalpine to the nival zone, harbouring high alpha and beta diversity. However, it includes also parts of the ski resort with infrastructures for Alpine winter tourism.

The subalpine zone $(1930-2300 \mathrm{~m})$ is characterized by Pinus cembra forests, subalpine grasslands, green alder and tall forb communities (Alnus alnobetula, Adenostyles alliariae), dwarf shrub communities (Rho- 

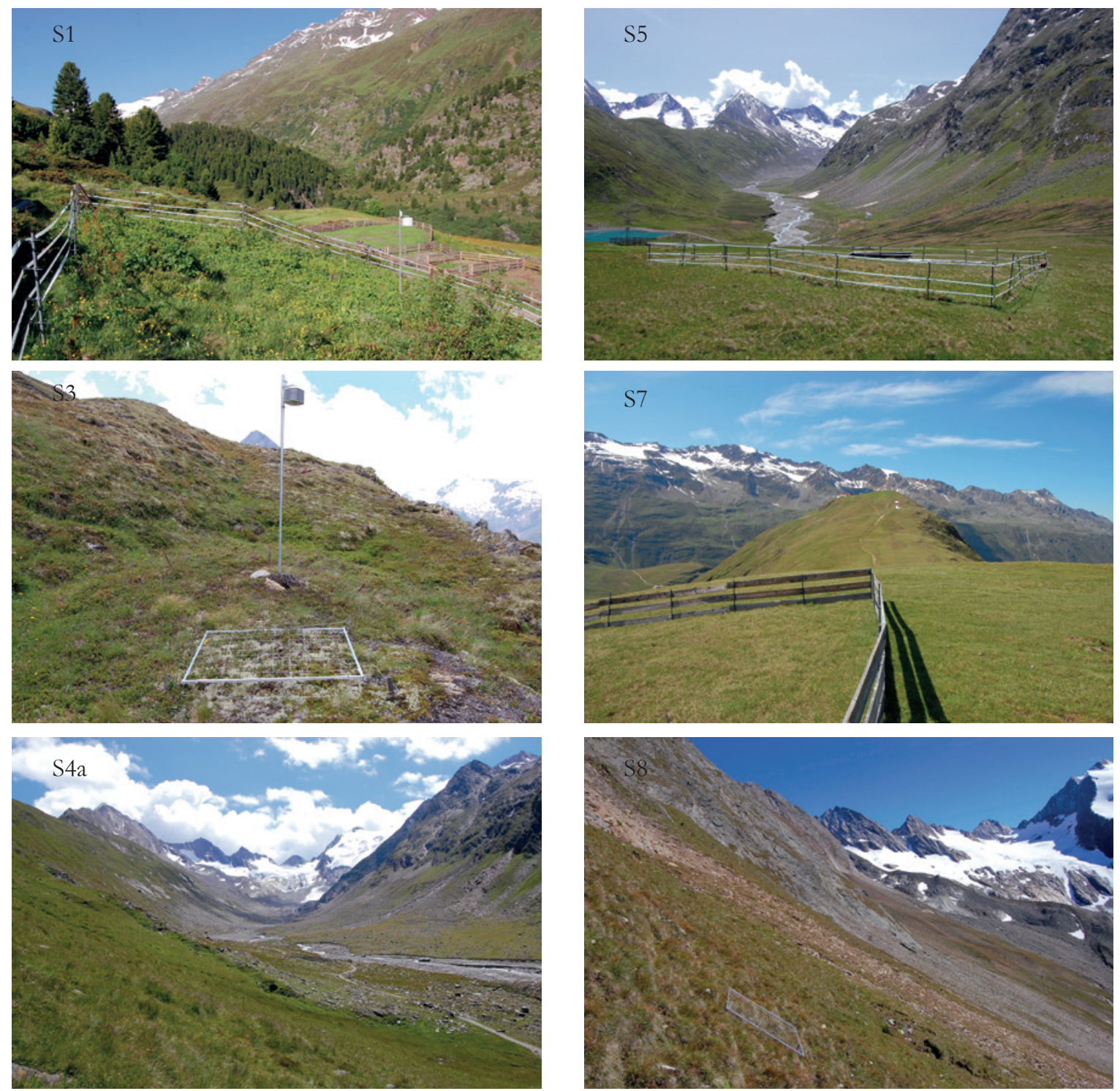

Figure 3 - Some of the monitoring sites at Gurgler Kamm BR. S1: Obergurgl; S5: Schönwieskopf; S3: lichen heath; S7: Hohe Mut; S4a: Rotmoos valley; S8: Kirchenkogel. (C) Roland Mayer

Table 1 - Monitoring sites at Gurgler Kamm BR (Obergurgl, Ötztal, Tyrol, Austria), altitude, locality, community, two most frequent species and sampling years. * Grazing exclusion sites (1 exclosure EX and 1 control CO). ** Grazing exclusion sites with three subsites each (3 EX, $3 \mathrm{CO})$.

\begin{tabular}{|l|l|l|l|l|r|}
\hline Site & Altitude & Locality & Community & Most frequent species & Sampling year \\
\hline S1* & $1960 \mathrm{~m}$ & Obergurgl & Subalpine pasture & Agrostis capillaris, Festuca rubra & $2000,2003-2006,2008,2011$ \\
\hline S2 & $2080 \mathrm{~m}$ & Rumsoppen & Dwarf shrub heath & Vaccinium myrtillus, V. vitis-idaea & $2000,2003,2004,2008,2011$ \\
\hline S3 & $2250 \mathrm{~m}$ & Gurgler Heide & Lichen heath & Loiseleuria procumbens, Cetraria islandica & $2000,2003,2004,2008,2011$ \\
\hline S4a & $2300 \mathrm{~m}$ & Rotmoos Valley & Alpine grassland & Nardus stricta, Carex sempervirens & $2003,2004,2008,2011$ \\
\hline S4b* & $2300 \mathrm{~m}$ & Rotmoos Valley & Glacier foreland & Kobresia myorsuroides, Poa alpina & $2001,2003-2006,2008,2011$ \\
\hline S5** & $2300 \mathrm{~m}$ & Schönwieskopf & Alpine grassland & Nardus stricta, Scorzoneroides helvetica & $2000-2006,2008,2011$ \\
\hline RN* $^{*}$ & $2300 \mathrm{~m}$ & Rotmoos Valley & Bog & Nardus stricta, Carex nigra & $2005-2007,2011$ \\
\hline RC* $^{*}$ & $2300 \mathrm{~m}$ & Rotmoos Valley & Bog & Carex nigra, Eriophorum angustifolium & $2005-2007,2011$ \\
\hline RT* $^{*}$ & $2300 \mathrm{~m}$ & Rotmoos Valley & Bog & $\begin{array}{l}\text { Trichophorum cespitosum, } \\
\text { Eriophorum angustifolium }\end{array}$ & $2005-2007,2011$ \\
\hline S6a & $2350 \mathrm{~m}$ & Festkogel ski piste & Ski piste grassland & Festuca rubra, Poa alpina & $2000,2003,2004,2008,2011$ \\
\hline S6b & $2350 \mathrm{~m}$ & Festkogel ski piste & Dwarf shrub heath & Loiseleuria procumbens, Avenula versicolor & $2000,2003,2004,2008,2011$ \\
\hline GF & $2490 \mathrm{~m}$ & Rotmoos Valley & Glacier foreland & Saxifraga aizoides, Saxifraga oppositifolia & 2011 \\
\hline S7** & $2600 \mathrm{~m}$ & Hohe Mut & Alpine grassland & Carex curvula, Avenula versicolor & $2000-2006,2008,2011$ \\
\hline S8 & $2790 \mathrm{~m}$ & Kirchenkogel & Alpine grassland & Festuca pumila, Kobresia myosuroides & $2000,2003,2004,2008,2011$ \\
\hline LN & $2790 \mathrm{~m}$ & Liebener Rippe & Alpine grassland & Kobresia myorsuroides, Thamnolia vermicularis & 2011 \\
\hline LS & $2830 \mathrm{~m}$ & Liebener Rippe & Snow bed & Polytrichum sp., Erigeron uniflorus & 2011 \\
\hline
\end{tabular}




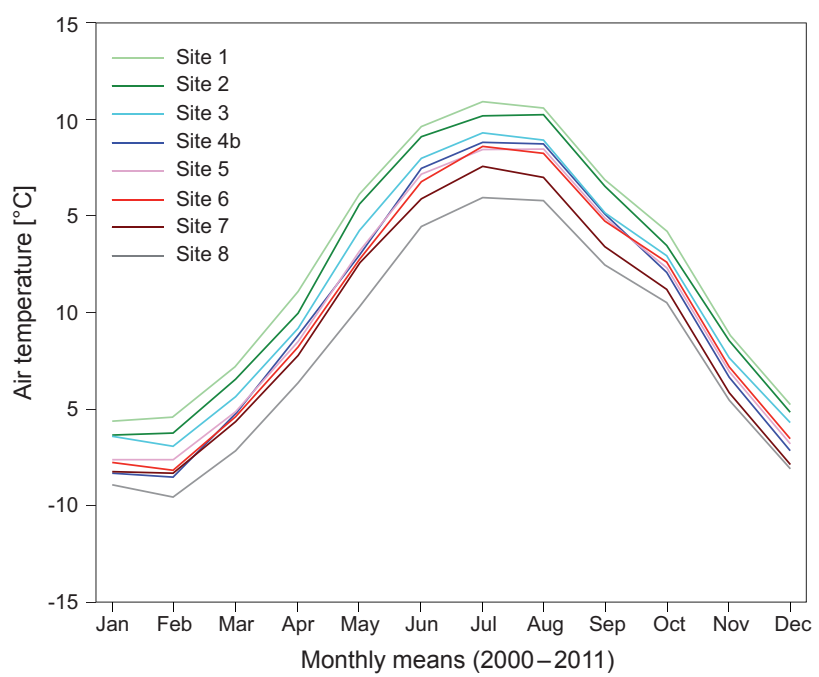

Figure 4-Monthly means of air temperatures $2 m$ above soil surface at 8 monitoring sites in Gurgler Kamm BR (means were calculated for the period 2000-2011, Hartl et al. 2013). For description of the sites, see Table 1.

dodendron ferrugineum, Vaccinium spp., Empetrum hermaphroditum, Loiseleuria procumbens) and boulder communities (Crytogramma crispa, Salix helvetica). In the alpine zone (2300-2800 m), grasslands (Carex curvula), snow beds (Salix herbacea, Polytrichum norvegicum), subnival scree and rock crevice communities (Saxifraga bryoides, Achillea moschata) prevail. Primary succession can be observed along the glacier forelands. Considerable diversity occurs up to more than 3400 m with Ranunculus glacialis, Saxifraga oppositifolia and Androsace alpina at the highest altitudes.

\section{Field work}

In the course of 11 years, a total of 16 monitoring sites (6 grazing exclusion sites and 10 untreated sites) were established along an altitudinal gradient from $1960 \mathrm{~m}$ to $2830 \mathrm{~m}$ (Table 1, Figure 3). At 9 out of 16 monitoring sites, data loggers continuously register the microclimate, i.e. air temperatures $2 \mathrm{~m}$ above the soil surface (Figure 4) and soil temperatures at a depth of $10 \mathrm{~cm}$ (Hartl et al. 2013).

All untreated sites are regularly grazed by sheep during summer. Within an area of approximately 40000 ha, ca. 3000 to 3500 sheep roam around during summer time. The stocking rates at the grazing exclusion sites at the BR are reported in Mayer et al. (2009): S1 is grazed by cattle; S4b by sheep and horses; S5 by sheep, goats, horses; S7 by sheep; RN, RC and RT by horses and occasionally by sheep. The numbers did not change during the investigation period. Depending on the time of snow melt, grazing generally lasts from 1 June to 20 September. Only at S1 is grazing restricted to 40 days a year (i.e. 6 heads of cattle during daytime). No information exists on the numbers of wild grazers (marmots, hares, roe deer, chamois). $\mathrm{S} 1$ is privately owned, all other sites are of collective property, i.e. they are grazed by domestic ungulates from the Agrargemeinschaft (agricultural community).
Table 2 - Mean species number per $1 \mathrm{~m}^{2}$ and standard error (SE) at the first and the last monitoring (timetable see Table 1) at the grazing exclusion and control sites of the BR. RN, RC and RT: exclusion sites (electric fences) at the Rotmoos bog. EX: exclosure site and CO control site (outside).

\begin{tabular}{|l|r|r|r|r|}
\hline Species no. & \multicolumn{1}{|l|}{ Mean } & \multicolumn{1}{l|}{ SE } & \multicolumn{1}{l|}{ Mean } & \multicolumn{1}{l|}{ SE } \\
\hline Site & \multicolumn{2}{|l|}{ First monitoring } & \multicolumn{2}{l|}{ Last monitoring } \\
\hline S1EX & 28.3 & 1.5 & 25.3 & 3.8 \\
\hline S1CO & 32.3 & 2.1 & 35.3 & 3.1 \\
\hline S4bEX & 26.0 & 3.0 & 30.7 & 2.1 \\
\hline S4bCO & 19.3 & 4.0 & 29.7 & 3.8 \\
\hline S5EX & 21.0 & 1.1 & 19.9 & 2.5 \\
\hline S5CO & 18.8 & 2.4 & 21.7 & 2.0 \\
\hline RNEX & 19.7 & 1.2 & 17.7 & 1.5 \\
\hline RNCO & 21.3 & 4.0 & 20.3 & 3.5 \\
\hline RCEX & 11.0 & 3.6 & 14.0 & 2.6 \\
\hline RCCO & 15.0 & 2.6 & 18.0 & 1.7 \\
\hline RTEX & 7.0 & 1.0 & 6.3 & 0.6 \\
\hline RTCO & 6.7 & 0.6 & 7.3 & 0.6 \\
\hline S7EX & 17.1 & 0.8 & 17.2 & 5.0 \\
\hline S7CO & 18.1 & 2.2 & 21.3 & 3.2 \\
\hline
\end{tabular}

At the grazing exclusion sites S1, S5 and S7, wooden fences were established in 2000 and partly replaced by electric fences in 2011. At S1 and S4b, only one exclosure of $140 \mathrm{~m}^{2}$ exists, at S5 there are three exclosures of $146 \mathrm{~m}^{2}, 38 \mathrm{~m}^{2}$ and $26 \mathrm{~m}^{2}$, respectively, and at $\mathrm{S} 7$ three exclosures of $144 \mathrm{~m}^{2}, 31 \mathrm{~m}^{2}$ and $34 \mathrm{~m}^{2}$, respectively. In 2005, three new exclusion sites (electric fences) were added at the Rotmoos bog: RN, RC and RT (one exclosure each, $144 \mathrm{~m}^{2}$, Mayer \& Erschbamer 2011).

At each untreated site, six permanent plots of $1 \mathrm{~m}^{2}$ were marked. At each grazing exclusion site, three plots of $1 \mathrm{~m}^{2}$ were marked within each exclosure (EX) and three outside as controls (CO), resulting in a total of 108 plots of $1 \mathrm{~m}^{2}$. Each permanent plot was monitored once during the growing season according to the time schedule in Table 1 by means of a frequency frame, divided into 100 subplots of $10 \mathrm{~cm}$ x $10 \mathrm{~cm}$. The frequency of the species was given in percent related to the 100 subplots. The frequencies were summed up into functional groups, i.e. dwarf shrubs, herbs, legumes, graminoids, bryophytes and lichens.

\section{Statistics}

Changes at grazing exclusion sites and their controls were calculated separately from the other monitoring sites, which were not treated by exclusion. Frequency counts and species numbers from 2000 to 2011 were analysed by a repeated ANOVA performed in PASW Statistics 18 (formerly SPSS; Polar Engineering and Consulting 1993-2007). The years were treated as factors of the repeated measure (innersubject variable). For all grazing exclusion sites, the variables year, exclosure and the interaction effect of these variables (year* exclosure) were calculated. For all naturally grazed monitoring sites only the variable year was calculated. 
Table 3 - Results of repeated ANOVA application: effects of year, exclusion and year* exclusion on the number of species at four grazing exclusion sites. $S Q=$ sum of squares, $d f=$ degrees of freedom, $F=F$-value, Sign $=p$-values $(p \leq 0.05$ in bold $)$.

\begin{tabular}{|l|l|r|r|c|c|}
\hline Site & Effect Species no. & \multicolumn{1}{|c|}{ SQ } & df & F & Sign. \\
\hline S1 & year & 147.667 & 6 & 5.188 & $\mathbf{0 . 0 0 2}$ \\
\hline & error year & 114.286 & 24 & & \\
\hline & exclusion & 176.095 & 1 & 9.222 & $\mathbf{0 . 0 3 9}$ \\
\hline & error exclusion & 76.381 & 4 & & \\
\hline & year ${ }^{*}$ exclusion & 176.905 & 6 & 6.192 & $<\mathbf{0 . 0 0 1}$ \\
\hline S4b & year & 278.143 & 6 & 14.299 & $<\mathbf{0 . 0 0 1}$ \\
\hline & error year & 77.810 & 24 & & \\
\hline & exclusion & 106.881 & 1 & 1.473 & 0.292 \\
\hline & error exclusion & 290.190 & 4 & & \\
\hline & year exclusion & 40.619 & 6 & 2.088 & 0.092 \\
\hline S5 & year & 53.567 & 8 & 4.157 & $\mathbf{0 . 0 0 2}$ \\
\hline & error year & 51.543 & 32 & & \\
\hline & exclusion & 3.461 & 1 & 0.183 & 0.691 \\
\hline & error exclusion & 75.627 & 4 & & \\
\hline & year *exclusion & 16.873 & 8 & 1.309 & 0.274 \\
\hline S7 & year & 237.967 & 8 & 12.705 & $<\mathbf{0 . 0 0 1}$ \\
\hline & error year & 74.920 & 32 & & \\
\hline & exclusion & 74.295 & 1 & 1.755 & 0.256 \\
\hline & error exclusion & 169.293 & 4 & & \\
\hline & year* exclusion & 10.840 & 8 & 0.579 & 0.788 \\
\hline
\end{tabular}

\section{Results}

Diversity and effects of grazing exclusion

At the first monitoring, diversity was highest at S1, with a mean of 28 species per $1 \mathrm{~m}^{2}$ in the exclusion plots and 32 in the control plots. At the last monitoring, 25 and 35 species, respectively, were recorded at S1 (Table 2). The lowest diversity occurred at the wettest sites of the Rotmoos bog (RTEX and RTCO, Table 2) with 6-7 species per $1 \mathrm{~m}^{2}$.

Grazing exclusion generally led to decreases in the number of species whereas diversity increased in the control plots (Figure 5). A clear trend of divergent development can be recognized after 11 years at site S7 (Figure 6). Similar trends were also observed at the exclusion sites S1 and S5. Results of the repeated ANOVA application showed significant effects of time on species numbers at all the exclusion sites (Table 3). Significant grazing exclusion effects were detected only at S1 (Table 3).

At S4b (glacier foreland), species numbers increased in the exclusion sites as well as in the control plots (Table 2).

Grazing effects on functional groups were detected at $\mathrm{S} 1$, with significant decreases of dwarf shrub and legume frequencies in the exclosures (EX, Table 4). However, all other functional groups also presented decreasing trends in the exclosures (years ${ }^{*} E X$, Table 4). At site S7, herbs exhibited a significantly decreasing trend in the exclosures. At RN, dwarf shrubs were negatively affected by grazing (EX, Table 4). At RC and $\mathrm{RT}$, bryophytes had an increasing trend in the exclosures; at RC, this also holds for graminoids (Table 4).
Table 4 - Results of repeated ANOVA application: effects of years, exclusion (EX) and years ${ }^{*} \mathrm{EX}$ on the frequency of functional groups at the 7 grazing exclusion sites; $p \leq 0.05$ in bold; trend: ث increasing in $\mathrm{EX}, \Omega$ decreasing in $\mathrm{EX}$.

\begin{tabular}{|c|c|c|c|c|c|}
\hline Site & Functional group & Years & EX & Years * EX & Trend \\
\hline \multirow[t]{6}{*}{ S1 } & total & $<0.001$ & 0.009 & $<0.001$ & $\sqrt{2}$ \\
\hline & dwarf shrubs & 0.010 & 0.039 & $<0.001$ & $\sqrt{2}$ \\
\hline & graminoids & $<0.001$ & 0.392 & 0.023 & $\sqrt{2}$ \\
\hline & herbs & $<0.001$ & 0.226 & 0.027 & $\sqrt{2}$ \\
\hline & legumes & 0.076 & 0.023 & 0.002 & $\sqrt{2}$ \\
\hline & bryophytes & $<0.001$ & 0.086 & 0.002 & $\sqrt{2}$ \\
\hline \multirow[t]{6}{*}{$\mathrm{S} 4 \mathrm{~b}$} & total & $<0.001$ & 0.975 & 0.897 & \\
\hline & graminoids & $<0.001$ & 0.350 & 0.267 & \\
\hline & herbs & $<0.001$ & 0.870 & 0.804 & \\
\hline & legumes & $<0.001$ & 0.651 & 0.484 & \\
\hline & bryophytes & $<0.001$ & 0.210 & 0.589 & \\
\hline & lichens & $<0.001$ & 0.260 & 0.411 & \\
\hline \multirow[t]{5}{*}{ S5 } & total & $<0.001$ & 0.938 & 0.911 & \\
\hline & graminoids & $<0.001$ & 0.658 & 0.277 & \\
\hline & herbs & $<0.001$ & 0.472 & 0.608 & \\
\hline & bryophytes & 0.008 & 0.899 & 0.980 & \\
\hline & lichens & 0.193 & 0.400 & 0.514 & \\
\hline \multirow[t]{5}{*}{ S7 } & total & $<0.001$ & 0.184 & 0.023 & $\sqrt{2}$ \\
\hline & graminoids & $<0.001$ & 0.789 & 0.607 & \\
\hline & herbs & $<0.001$ & 0.205 & 0.025 & $\sqrt{2}$ \\
\hline & bryophytes & $<0.001$ & 0.639 & 0.198 & \\
\hline & lichens & $<0.001$ & 0.909 & 0.957 & \\
\hline \multirow[t]{6}{*}{$\mathrm{RN}$} & total & 0.002 & 0.298 & 0.080 & \\
\hline & dwarf shrubs & 0.091 & 0.022 & 0.188 & \\
\hline & graminoids & 0.002 & 0.670 & 0.561 & \\
\hline & herbs & 0.004 & 0.531 & 0.133 & \\
\hline & bryophytes & $<0.001$ & 0.552 & 0.099 & \\
\hline & lichens & 0.491 & 0.392 & 0.363 & \\
\hline \multirow[t]{5}{*}{$\mathrm{RC}$} & total & $<0.001$ & 0.386 & 0.133 & \\
\hline & dwarf shrubs & 0.126 & 0.078 & 0.766 & \\
\hline & graminoids & $<0.001$ & 0.743 & 0.019 & 仓 \\
\hline & herbs & $<0.001$ & 0.197 & 0.770 & \\
\hline & bryophytes & 0.148 & 0.213 & 0.023 & $\hat{\imath}$ \\
\hline \multirow[t]{4}{*}{ RT } & total & $<0.001$ & 0.355 & 0.932 & \\
\hline & graminoids & $<0.001$ & 0.765 & 0.524 & \\
\hline & herbs & 0.098 & 0.520 & 0.618 & \\
\hline & bryophytes & $<0.001$ & 0.485 & 0.038 & 仓े \\
\hline
\end{tabular}

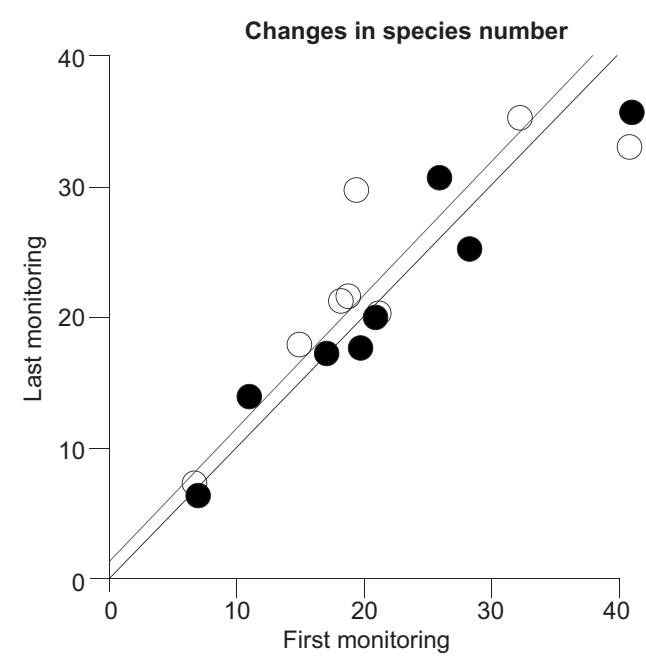

Figure 5 - Scatter plot of the grazing exclusion $(\bullet)$ and control sites (O), comparing the first and the last monitoring results. 

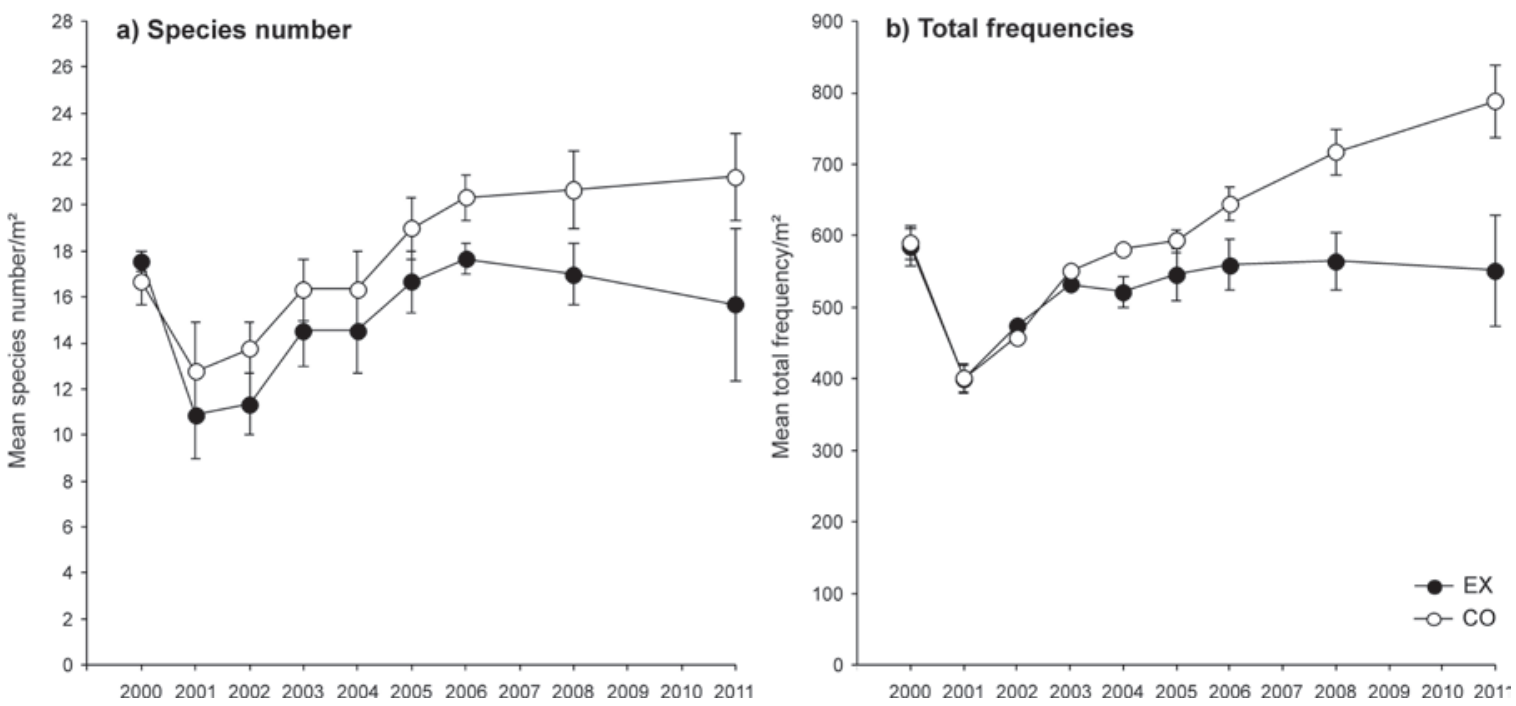

Figure 6 - Species number (a) and total frequencies (b) at site S7 in the exclosure (EX) and control plots (CO) from 2000 till 2011. Means and standard errors are shown.

Table 5 - Mean species number per $1 \mathrm{~m}^{2}$ and standard error (SE) at the first and the last monitoring at the untreated sites of the BR.

\begin{tabular}{|l|r|r|l|r|}
\hline Species no. & Mean & \multicolumn{1}{l|}{ SE } & Mean & \multicolumn{1}{l|}{ SE } \\
\hline Site & \multicolumn{1}{|l|}{ First monitoring } & \multicolumn{2}{|l|}{ Last monitoring } \\
\hline S2 & 20.3 & 3.9 & 25.5 & 1.6 \\
\hline S3 & 21.2 & 6.0 & 21.8 & 6.4 \\
\hline S4a & 30.3 & 3.7 & 36.8 & 4.7 \\
\hline S6a & 17.7 & 6.8 & 27.0 & 2.6 \\
\hline S6b & 23.0 & 1.7 & 28.0 & 5.3 \\
\hline GF & 3.5 & 1.9 & \multicolumn{2}{|c|}{ no value } \\
\hline S8 & 23.4 & 3.5 & 25.8 & 1.8 \\
\hline LN & 38.0 & 4.1 & \multicolumn{2}{|c|}{ no value } \\
\hline LS & 30.5 & 3.1 & \multicolumn{3}{|c|}{ no value } \\
\hline
\end{tabular}

Table 6 - Results of repeated ANOVA application, with species number as dependent variable and year as fixed variable at the untreated sites. $S Q=$ sum of squares, $d f=$ degree of freedom, $F=F$-value, Sign $=p$-values $(p \leq 0.05$ in bold $)$.

\begin{tabular}{|l|l|r|r|l|l|}
\hline Site & Effect Species no. & SQ & df & F & Sign. \\
\hline S2 & year & 141.200 & 4 & 8.695 & $<\mathbf{0 . 0 0 1}$ \\
\hline & error year & 81.200 & 20 & & \\
\hline S3 & year & 7.500 & 4 & 0.630 & 0.650 \\
\hline & error year & 35.700 & 12 & & \\
\hline S4a & year & 274.972 & 3 & 46.641 & $<\mathbf{0 . 0 0 1}$ \\
\hline & error year & 29.458 & 15 & & \\
\hline S6a & year & 198.400 & 4 & 20.667 & $<\mathbf{0 . 0 0 1}$ \\
\hline & error year & 19.200 & 8 & & \\
\hline S6b & year & 65.333 & 4 & 2.140 & 0.167 \\
\hline & error year & 61.067 & 8 & & \\
\hline S8 & year & 125.667 & 4 & 5.843 & $\mathbf{0 . 0 0 3}$ \\
\hline & error year & 107.533 & 20 & & \\
\hline
\end{tabular}

\section{Diversity at the untreated sites}

The highest diversity per plot (38 species per $1 \mathrm{~m}^{2}$, Table 5) was found at the alpine grassland of the Liebener Rippe, the lowest species number resulted at the recently deglaciated plots of the Rotmoosferner glacier foreland (3-4 species per $1 \mathrm{~m}^{2}$, Table 5).

Diversity increased considerably over the years at the untreated sites (Table 5). With exception of S3 and S6b, all untreated sites exhibited significant effects of the factor year on species number (Table 6). More or less all functional groups were involved in these increases (Table 7). The weakest trends were found at S3. Here, only graminoids showed an increasing trend (Table 7).

Considering all untreated sites, no appearance of species from lower altitudes were recorded at all.

\section{Discussion}

The results of increasing species numbers at the untreated sites are in line with the overall trends during recent decades at high altitudes (Pauli et al. 2007, 2012; Lenoir et al. 2008; Erschbamer et al. 2011; Gottfried et al. 2012). Revisitations of summit floras in the Alps revealed an upward migration of species and an increase in species richness due to increases in mean surface air temperature (Meehl et al. 2007; Gottfried et al. 2012; Pauli et al. 2012). The diversity increase can also be confirmed in the BR Gurgler Kamm from the subalpine to the subnival zone. However, up to now no clear signs of upward migrations of species from lower altitudes were detected at our monitoring sites.

Very low changes were observed in the lichen heath (S3). This dense Loiseleuria procumbens-lichen carpet can be regarded as a highly stable community and we assume that it may be the most resistant one against invasions by species from lower altitudes.

Clear grazing effects were detected in the subalpine zone. Here, the control plots enhanced species num- 
bers and frequencies substantially. In contrast, the frequencies of dwarf shrubs (Calluna vulgaris, Vaccinium spp.) and legumes (Trifolium spp. and Lotus corniculatus) decreased significantly in the exclosure plots. Similarly, an increase of Fabaceae in grazed ecosystems due to the presence of gaps was noticed for instance by Dupré \& Diekmann (2001). In our case, the increase was most likely enhanced due to mineral fertilization of the grazed control plots by the farmer. Severe increases of tall herbs in the exclosure plots, visible already after 7 years of grazing exclusion (Mayer et al. 2009), were frequently found after grazing cessation in different plant communities (Mayer \& Grabner 2004; Pajunen et al. 2008; Medina-Roldàn et al. 2012). As a consequence of increased tall herb abundance, dwarf shrubs were found to be the losers in the subalpine exclosure. These findings contrast with results reported from arctic environments, where reindeer grazing mainly reduced the abundance of dwarf shrubs (Väre et al. 1996). The contrasting results can be attributed to the differences in grazers, plant communities and climate.

With increasing altitude, the effects of grazing decreased. Species numbers did not change significantly in the lower and upper alpine grazing exclusions in the course of 11 years. However, functional groups shifted considerably. At S7, herbs showed a significant decreasing trend, probably due to the enhanced growth of the dominant grassland species Carex curvula in the exclosures. Also at S5, temporal shifts of all functional groups were recorded. We point out that only over the longer term are divergent reactions of functional groups visible in exclosures and controls.

Within two exclosures of the Rotmoos bog, graminoids and bryophytes were found to have a significant increasing trend. The increase of bryophytes is in line with results of Virtanen (2000) who found increasing bryophyte biomass production even after short-term grazing exclusions of 5 years in a mountain snow bed in NW Finland. Eskelinen \& Oksanen (2006) found that graminoids declined after grazing reduction. In contrast, at the RC site, graminoids and at RN site, dwarf shrubs showed a positive effect in the exclosure plots.

Highest increases in species numbers were recorded at $\mathrm{S} 4 \mathrm{~b}$, i. e. at the 1858 moraine of the Rotmoosferner glacier foreland. Here, primary succession is acting on both controls and exclosures. On both sampling sites a high increase in species numbers and frequencies was detected. All functional groups were increasing more or less equally, showing the high dynamic of this initial grassland at the glacier foreland. The grassland has mean cover values of 67\% (Raffl \& Erschbamer 2004; Raffl et al. 2006). Obviously, the open patches within this site allow new colonization in grazed as well as in ungrazed plots. Due to the high variability of the plots, differences between exclosures and controls were not really detectable.
Table 7 - Results of repeated ANOVA application: effects of years on the frequency of functional groups at the untreated sites. $S Q=$ sum of squares, $d f=$ degree of freedom, $F=F$-value, $p \leq 0.05$ in bold; Trend: $仑$ increasing in EX, 占 decreasing in $\mathrm{EX}$.

\begin{tabular}{|c|c|c|c|c|c|c|}
\hline Site & Functional group & QS & df & $\mathbf{F}$ & Years & Trend \\
\hline \multirow[t]{5}{*}{ S2 } & total & 554643.333 & 4 & 50.475 & $<0.001$ & 仓 \\
\hline & dwarf shrubs & 73329.467 & 4 & 15.345 & $<0.001$ & 仓 \\
\hline & graminoids & 3031.000 & 4 & 7.475 & 0.001 & 仓े \\
\hline & herbs & 80571.867 & 4 & 18.380 & $<0.001$ & 仓े \\
\hline & bryophytes & 17588.333 & 4 & 28.619 & $<0.001$ & 仓 \\
\hline \multirow[t]{6}{*}{ S3 } & total & 21183.500 & 4 & 1.860 & 0.182 & \\
\hline & dwarf shrubs & 10075.700 & 4 & 2.952 & 0.065 & \\
\hline & graminoids & 1189.700 & 4 & 5.592 & 0.009 & $\hat{\imath}$ \\
\hline & herbs & 2299.800 & 4 & 1.716 & 0.211 & \\
\hline & bryophytes & 477.500 & 4 & 0.727 & 0.590 & \\
\hline & lichens & 5680.800 & 4 & 1.987 & 0.161 & \\
\hline \multirow[t]{5}{*}{ S4a } & total & 628780.458 & 3 & 85.149 & $<0.001$ & 仓े \\
\hline & graminoids & 2523.500 & 3 & 6.126 & 0.006 & 仓 \\
\hline & herbs & 186767.500 & 3 & 36.983 & $<0.001$ & 仓े \\
\hline & legumes & 169.458 & 3 & 0.863 & 0.481 & \\
\hline & bryophytes & 405.000 & 3 & 2.811 & 0.075 & \\
\hline \multirow[t]{6}{*}{ S6a } & total & 330602.267 & 4 & 19.639 & $<0.001$ & 仓े \\
\hline & dwarf shrubs & 274.667 & 4 & 0.818 & 0.548 & \\
\hline & graminoids & 6631.600 & 4 & 6.293 & 0.014 & 认 \\
\hline & herbs & 68875.067 & 4 & 18.610 & $<0.001$ & 仓 \\
\hline & bryophytes & 24234.267 & 4 & 21.902 & $<0.001$ & 仓 \\
\hline & lichens & 8509.333 & 4 & 2.984 & 0.088 & \\
\hline \multirow[t]{6}{*}{ S6b } & total & 256382.267 & 4 & 7.844 & 0.007 & 仓े \\
\hline & dwarf shrubs & 3663.067 & 4 & 1.751 & 0.232 & \\
\hline & graminoids & 18862.400 & 4 & 8.068 & 0.007 & 仓े \\
\hline & herbs & 86831.067 & 4 & 11.163 & 0.002 & 仓 \\
\hline & bryophytes & 2793.067 & 4 & 3.273 & 0.072 & \\
\hline & lichens & 5686.400 & 4 & 5.987 & 0.016 & $\hat{\imath}$ \\
\hline \multirow[t]{5}{*}{ S8 } & total & 402233.133 & 4 & 22.581 & $<0.001$ & 仓 \\
\hline & graminoids & 6756.467 & 4 & 4.605 & 0.008 & $\hat{\imath}$ \\
\hline & herbs & 74782.467 & 4 & 16.844 & $<0.001$ & 仓 \\
\hline & legumes & 556.867 & 4 & 4.941 & 0.006 & 仓 \\
\hline & bryophytes & 21379.533 & 4 & 24.615 & $<0.001$ & $\hat{\imath}$ \\
\hline
\end{tabular}

\section{Conclusions}

In contrast to the majority of ecological studies, which last three years at most, our monitoring study is unique, being (i) a long-term project and (ii) covering the whole gradient from subalpine pastures, dwarf shrub communities and ski runs to alpine grasslands, subnival grasslands and recently deglaciated moraines. Grazing effects were found to be significant at the subalpine zone. After 11 years, frequencies as well as species numbers already showed a contrasting development in all exclosure and control plots along the whole altitudinal gradient, though this was not significant at higher altitudes. However, the diverging tendency will be much more consistent in the longer term.

From the 11-year monitoring it can be concluded that species diversity will be negatively affected by grazing exclusion along the whole altitudinal gradient. Our results support the intermediate disturbance bypothesis predicting an increase of diversity under medium to low grazing pressure (Milchunas \& Lauenroth 1993; 
Proulx \& Mazumder 1998). The hypothesis, defined for lowland ecosystems, is also valid for high altitude grasslands. We therefore suggest continuing with the same number of sheep traditionally grazing in the BR and in the Natura 2000 area Ötztaler Alpen in order to avoid shifts in species composition and richness. Our results will be further refined after another monitoring in 2014 and suggestions will be included in a future management plan of Ötztal Nature Park. At present no management programme exists but directives have already been discussed.

\section{Acknowledgements}

The long-term study was financially supported by the Environment Dept. of the Tyrolean Federal State Government, the Austrian Academy of Sciences' MAB Programme and the Mountain Agriculture Research Unit / University of Innsbruck. Many thanks to Ao. Univ-Prof. Dr. Rüdiger Kaufmann who was one of the initiators of the monitoring project and supported the statistical analyses during the first decade.

\section{References}

Altesor, A., M. Oesterheld, E. Leoni, F. Lezama \& C. Rodriguez 2005. Effect of grazing on community structure and productivity of a Uruguayan grassland. Plant Ecology 179: 83-91.

Binkley, D., F. Singer, M. Kaye \& R. Rochelle 2003. Influence of elk grazing on soil properties in Rocky Mountain National Park. Forest Ecology and Management 185: 239-247.

Bohner, A., F. Starlinger \& P. Koutecky 2012. Vegetation changes in an abandoned montane grassland, compared to changes in a habitat with low-intensity sheep grazing - a case study in Styria, Austria. eco.mont 4: 5-12.

Bortenschlager, S. 2000. The Iceman's environment. In: Bortenschlager S. \& K. Oeggl (eds.), The Iceman and his Natural Environment. Wien, New York: 11-24.

Bowman, W.D. \& T.R. Seastedt 2001. Structure and function of an alpine ecosystem. Niwot Ridge, Colorado. New York.

Buttolph, L.P. \& D.L. Coppock 2004. Influence of deferred grazing on vegetation dynamics and livestock productivity in an Andean pastoral system. Journal of Applied Ecology 41: 664-674.

Camenisch, M. \& M. Schütz 2000. Temporal and spatial variability of the vegetation in a four-year exclosure experiment in Val Trupchun (Swiss National Park). In: Schütz, M., B.O. Krüsi \& P.J. Edwards (eds.,) Succession research in the Swiss National Park. Volume 89, Nationalpark Forschung Schweiz, Zernez: 165-188.

Deléglise, C., G. Loucougaray \& D. Alard 2011. Spatial patterns of species and plant traits in response to 20 years of grazing exclusion in subalpine grassland communities. Journal of Vegetation Science 22: 402-413.
Dullinger, S., T. Dirnböck, J. Greimler \& G. Grabherr 2003. A resampling approach for evaluating effects of pasture abandonment on subalpine plant species diversity. Journal of Vegetation Science 14: 243-252.

Dupré, C. \& M. Diekmann 2001. Differences in species richness and life-history traits between grazed and abandoned grasslands in southern Sweden. Eco graphy 24: 275-286.

Erschbamer, B. \& R. Kaufmann 2006. Perspectives for Gurgler Kamm Biosphere Reserve (Ötztal, Tyrol, Austria). In: Price, M.F. (ed.), Global change in mountain regions. Duncow: 305.

Erschbamer, B., M. Mallaun \& P. Unterluggauer 2006. Plant diversity along altitudinal gradients in the Southern and Central Alps of South Tyrol and Trentino (Italy). Gredleriana 6: 1-22.

Erschbamer, B., T. Kiebacher, M. Mallaun \& P. Unterluggauer 2009. Short-term signals of climate change along an altitudinal gradient in the South Alps. Plant Ecology 202: 79-89.

Erschbamer, B., P. Unterluggauer, E. Winkler \& M. Mallaun 2011. Changes in plant species diversity revealed by long-term monitoring on mountain summits in the Dolomites (Northern Italy). Preslia 83: 387-401.

Eskelinen, A. \& J. Oksanen 2006. Changes in abundance, composition and species richness of mountain vegetation in relation to summer grazing by reindeer. Journal of Vegetation Science 17: 245-254.

Gärtner, G. 2010. Zur Kryptogamenflora im Rotmoostal. In: Koch, E.-M. \& B. Erschbamer (Hrsg.), Glaziale und periglaziale Lebensräume im Raum Obergurgl, Alpine Forschungsstelle Obergurgl Volume 1. Innsbruck: 145-154.

Gottfried, M., H. Pauli, A. Futschik, M. Akhaltkatsi, P. Barancok, J.L. Benito Alonso, G. Coldea, J. Dick, B. Erschbamer, M.R. Fernández Calzado, G. Kazakis, J. Krajci, P. Larsson, M. Mallaun, O. Michelsen, D. Moiseev, P. Moiseev, U. Molau, A. Merzouki, L. Nagy, G. Nakhutsrishvili, B. Pedersen, G. Pelino, M. Puscas, G. Rossi, A. Stanisci, J.-P. Theurillat, M. Tomaselli, L. Villar, P. Vittoz, I. Vogiatzakis \& G. Grabherr 2012. Continent-wide response of mountain vegetation to climate change. Nature Climate Change 2: 111-115.

Hartl, L., R. Kaufmann, N. Schallhart \& B. Erschbamer 2013. Das Mikroklima waldfreier Standorte in der subalpinen, alpinen und subnivalen Stufe in Obergurgl. In: Koch, E.M. \& B. Erschbamer (Hrsg.), Klima, Wetter, Gletscher im Wandel. Alpine Forschungsstelle Obergurgl Volume 3. Innsbruck: 99-120.

Holzinger, B., K. Hülber, M. Camenisch \& G. Grabherr 2008. Changes in plant species richness over the last century in the eastern Swiss Alps: elevational gradient, bedrock effects and migration rates. Plant Ecology 195: 179-196.

IPCC 2007. Climate Change 2007: Synthesis Report. Contribution of Working Groups I, II and III to the Fourth Assessment Report of the Intergovernmental Panel on Climate Change. Pachauri, R.K. \& A. Reisinger (eds.), IPCC, Geneva, Switzerland. 
Isselstein, J., B.A. Griffith, P. Pradel \& S. Venerus 2007. Effects of livestock breed and grazing intensity on biodiversity and production in grazing systems. 1 . Nutritive value of herbage and livestock performance. Grass and Forage Science 62: 145-158.

Jewell, P.L., D. Kauferle, S. Gusewell, N.R. Berry, M. Kreuzer \& P.J. Edwards 2007. Redistribution of phosphorus by cattle on a traditional mountain pasture in the Alps. Agriculture, Ecosystems \& Environment 122: 377-386.

Kala, C.P., S.K. Singh \& G.S. Rawat 2002. Effects of sheep and goat grazing on the species diversity in the alpine meadows of Western Himalaya. The Environmentalist 22: 183-189.

Kaufmann, R. 2005. Langzeit-Ökosystem Monitoring im Alpinen Raum. Endbericht 2000-2005. Amt der Tiroler Landesregierung, Abteilung Umweltschutz, unpubl. Report.

Kuhn, M., E. Dreiseitl \& M. Emprechtinger 2013. Temperatur und Niederschlag an der Wetterstation Obergurgl, 1953-2011. In: Koch, E.-M. \& B. Erschbamer (Hrsg.), Klima, Wetter, Gletscher im Wandel. Alpine Forschungsstelle Obergurgl. Volume 3. Innsbruck: $11-31$.

Lenoir, J., J.C. Gégout, P.A. Marquet, P. de Ruffray \& H. Brisse 2008. A significant upward shift in plant species optimum elevation during the $20^{\text {th }}$ century. Science 320: 1768-1771.

Mayer, R. \& S. Grabner 2004. Die Vegetation der Bergmähder im Valsertal/Tirol. Tuexenia 24: 227-245.

Mayer, R., R. Kaufmann, K. Vorhauser \& B. Erschbamer 2009. Effects of grazing exclusion on species composition in high-altitude grassland of the Central Alps. Basic and Applied Ecology 10: 447-455.

Mayer, R. \& B. Erschbamer 2011. Seedling recruitment and seed-/microsite limitation in traditionally grazed plant communities of the alpine zone. Basic and Applied Ecology 12: 10-20.

Medina-Roldàn, E., J. Paz-Ferreiro \& R.D. Bardgett 2012. Grazing exclusion affects soil and plant communities, but has no impact on soil carbon storage in an upland grassland. Agriculture, Ecosystems and Environment 149: 118-123.

Meehl, G.A., T.F. Stocker, W.D. Collins, P. Friedlingstein, A.T. Gaye, J.M. Gregory, A. Kitoh, R. Knutti, J.M. Murphy, A. Noda, S.C.B. Raper, I.G. Watterson, A.J. Weaver \& Z.-C. Zhao 2007. Global Climate Projections. In: Solomon, S., D. Qin, M. Manning, Z. Chen, M. Marquis, K.B. Averyt, M. Tignor \& H.L. Miller (eds.), Climate Change 2007: The Physical Science Basis. Contribution of Working Group I to the Fourth Assessment Report of the Intergovernmental Panel on Climate Change. Cambridge, United Kingdom and New York, NY, USA.

Meixner, W. \& G. Sigl 2010. Historisches zum Thema Gletscher, Gletschervorfeld und Obergurgl. In: Koch, E.-M. \& B. Erschbamer (Hrsg.), Glaziale und periglaziale Lebensräume im Raum Obergurgl. Alpine
Forschungsstelle Obergurgl. Volume 1. Innsbruck: 13-29.

Milchunas, D.G. \& W.K. Lauenroth 1993. Quantitative effects of grazing on vegetation and soils over a global range of environments. Ecological Monographs 63: 327-366.

Miller, G.R., C. Geddes \& D.K. Mardon 2010. Effects of excluding sheep from an alpine dwarf-herb community. Plant Ecology and Diversity 3: 87-93.

Moser, W. 1987. Chronik von MaB-6 Obergurgl. In: Patzelt, G. (ed.), MaB-Projekt Obergurgl. Volume 10. Innsbruck: 7-25.

Pajunen, A., R. Virtanen \& H. Roininen 2008. The effects of reindeer grazing on the composition and species richness of vegetation in forest-tundra ecotone. Polar Biology 31: 1233-1244.

Raffl, C. \& B. Erschbamer 2004. Comparative vegetation analyses of two transects crossing a characteristic glacier valley in the Central Alps. Phytocoenologia 34: 225-240.

Raffl, C., M. Mallaun, R. Mayer \& B. Erschbamer 2006. Vegetation succession pattern and diversity changes in a glacier valley, Central Alps, Austria. Arctic, Antarctic, and Alpine Research 38: 421-428.

Patzelt, G. 1987. MAB-Projekt Obergurgl. Volume 10. Innsbruck

Pauli, H., M. Gottfried, K. Reiter, C. Klettner \& G. Grabherr 2007. Signals of range expansions and contractions of vascular plants in the high Alps: observations (1994-2004) at the GLORIA master site Schrankogel, Tyrol, Austria. Global Change Biology 13: 147-156.

Pauli, H., M. Gottfried, S. Dullinger, O. Abdaladze, M. Akhaltkatsi, J.L. Benito Alonso, G. Coldea, J. Dick, B. Erschbamer, R. Fernández Calzado, D. Ghosn, J. Holten, R. Kanka, R. Kazakis, J. Kollár, P. Larsson, D. Moiseev, P. Moiseev, U. Molau, J. Molero Mesa, L. Nagy, R. Pelino, M. Puscas, R. Rossi, A. Stanisci, A.O. Syverhuset, J.-P. Theurillat, M. Tomaselli, P. Unterluggauer, L. Villar, P. Vittoz \& G. Grabherr 2012. Recent plant diversity changes on Europe's mountain summits. Science 336: 353-355.

Pavlu, V., M. Hejcman, L. Pavlu \& J. Gaisler 2007. Restoration of grazing management and its effects on vegetation in an upland grassland. Applied Vegetation Science 10: 375-382.

Proulx, M. \& A. Mazumder 1998. Reversal of Grazing Impact on Plant Species Richness in Nutrient-Poor vs. Nutrient-Rich Ecosystems. Ecology 79: 2581-2592.

Schneiter, S. 1997. Die Reaktion eines alpinen Rasens auf die Aussetrung der Beweidung. Diploma Thesis, University of Basel.

Scheurer, T. 2000. The history of botanical studies and permanent plot research in the Swiss National Park. In: Schütz, M., B.O. Krüsi \& P.J. Edwards (eds.), Succession research in the Swiss National Park, Schweizerische Naturpark-Forschung 89: 9-25.

UNESCO 1995. Available at: www.unesco.org/ $\mathrm{mab} / \mathrm{doc} / \mathrm{brs} /$ Strategy.pdf 
Väre, H., R. Ohtonen \& K. Mikkola 1996. The effects and extent of heavy grazing by reindeer in oligotrophic pine heaths in northeastern Fennoscandia. Ecography 19: 245-253.

Virtanen, R. 2000. Effects of grazing on aboveground biomass on a mountain snowbed, NW Finland. Oikos 90: 295-300.

Vorren, K.-D., B. Mörkved \& S. Bortenschlager 1993. Human impact of the Holocene forest line in the Central Alps. Vegetation History and Archaeobotany 2: 145-156.

Walther, G.-R., S. Beißner \& C.A. Burga 2005. Trends in the upward shift of alpine plants. Journal of Vegetation Science 16: 542-548.

\section{Authors}

Mag. Dr. Roland Mayer

studied biology at the University of Innsbruck, Austria. He has been a member of the working group
Population Biology and Vegetation Ecology at the Institute of Botany, University of Innsbruck (http:// www.uibk.ac.at/botany/) since 2000. His research focuses on vegetation classification and mapping, longterm monitoring of high altitudinal ecosystems and on studying the effects of grazing cessation in den Central Alps. In 2011 he became scientific coordinator at Oetztal Nature Park.

\section{Univ.-Prof. Dr. Brigitta Erschbamer}

heads the working group Population Biology and Vegetation Ecology at the Institute of Botany (http:/ / www.uibk.ac.at/botany/). In 2009 she became scientific director of the Alpine Research Centre Obergurgl, University of Innsbruck (http://www.uibk.ac.at/ afo/). Her research projects concentrate on primary succession in glacier forelands, germination biology, climate change in high altitudes and effects of landuse changes. 